\title{
Livelihood Strategy of Coastal Community: A Case Study in Tanjung Saleh Islands, Kubu Raya District, Indonesia
}

\author{
Jajat Sudrajat ${ }^{1 \bowtie}$ \\ ${ }^{1}$ Department of Agricultural Socioeconomics, \\ Agriculture Faculty, Tanjungpura University, Pontianak-Indonesia \\ DOI: http://dx.doi.org/10.15294/komunitas.v8i1.4581 \\ Received : 1 December 2015; Accepted: 4 March 2016; Published: 31 March 2016
}

\begin{abstract}
This study is intended to identify the characteristic of livelihood strategy and to formulate the exit strategy from poverty trap in a coastal community. This study was done in Tanjung Saleh islands, one from 39 islands at Kubu Raya District, West Kalimantan Province, Indonesia. Data were collected by depth interviews, group interviews, observation, and literature study. The results of this study show that the livelihood strategies at Tanjung Saleh islands can be identified into five types: (a) the strategy that relied on the natural resources extraction, (b) traditional agriculture cultivation strategy, (c) household worker utilization strategy, (d) migration strategy, and (e) institutional strategy. The institutional strategy is categorized as exit strategy from poverty trap meanwhile the other strategies are categorized as survival strategy. Fact in the field shows that institutional strategy and the role of women are important factor to support the fishermen household livelihood system. There are two institutions often utilized in fishermen community, "arisan" (rotational saving and credit association) custom and patron client relationships between fishermen and village traders. Through the utilizing of social capital on both institutions, the fishermen household can access financial capital effectively. Therefore, the nurturing of social capital and the role of women must be considered in arrangement of sustainable livelihood strategies in fishermen community.
\end{abstract}

Keywords: livelihood strategy; fishermen; social capital; arisan

\section{INTRODUCTION}

Poverty reduction program is still main attention in Indonesian development. Generally, the poverty zone in Indonesia can be divided into three categories that are poverty in urban, inland, and coastal area. In this study, the poverty problems in coastal area become main attention (Fauzi, Savitri and Shohibuddin 2009; Balisacan, Pernia and Asra 2003; Cassels, Curran and Kramer 2005). This study is important in the way it empirically lays out th problems of poverty in coastal area.

Basically, the communities in island or coastal area always face some problems as cause of poverty. They depend on season and coastal resources which need costly investment in its utilization. Therefore, lack of infrastructure is one of factors that caused the poverty problems (Warr 2005; Suryahadi, Suryadarma and Sumarto 2009; 2005). This reality can be found at Tanjung Saleh islands, an area about 35 kilometers far from Pontianak City (a core region of West Kalimantan Province). This village is not categorized as remote area, but until now it is still isolated due to goegraphyc condition.

The poverty problem in this coastal area is ironic, especially if the problem is compared with potency of their natural resources. The coastal area in West Kalimantan has enormous natural resources

Corresponding author :

Address: J1. Sungai Raya Dalam Komplek Mitra Indah Utama 7 No. A-12 Pontianak

Email : sudrajat.jano@gmail.com

Telp : 081256045003

(C) 2016 Semarang State University. All rights reserved p-ISSN 2086 - 5465 | e-ISSN 2460-7320

UNNDS JOURNALS


potency. It is characterized by slight coastal slop and soil type that enough fertile. Therefore, there are some economic activities in this region not only in fisheries but also in agriculture sector such as food crops, plantation, livestock, etc.

In rural area, the livelihood diversification is often used to overcome every vulnerability context. Livelihood diversification is defined by Ellis (1998):

..... "as the process by which rural families construct a diverse portfolio of activities and social support capabilities in order to survive and to improve their standards of living...."

The diversification strategy can divided into two types, on farm and non farm employment. In last decade, the role of rural non farm employment (RNFE) and rural non farm income (RNFI) become more important when the village has evolved (Reardon et al., 2001).
Generally, the economic activities at Tanjung Saleh village are not evolving yet. Therefore, the fisherman households often face some vulnerability due to lack of employment opportunity. Refer to some vulnerability condition and lack of infrastructure, how does the people in this isolated coastal area arrange the livelihood strategies to guarantee their livelihood sustainability?. This reality is very interesting to be investigated in order to know some aspects which influence the sustainability of their livelihood. Based on this background particularly this study is aimed to identify the characteristic of livelihood strategy and to formulate the exit strategy from poverty trap in a coastal community.

\section{RESEARCH METHODS}

This study was done on August until November 2015 at Tanjung Saleh islands, one from 39 islands at Kubu Raya District, West Kalimantan Province (Figure 1). The election of this location is based on judgement

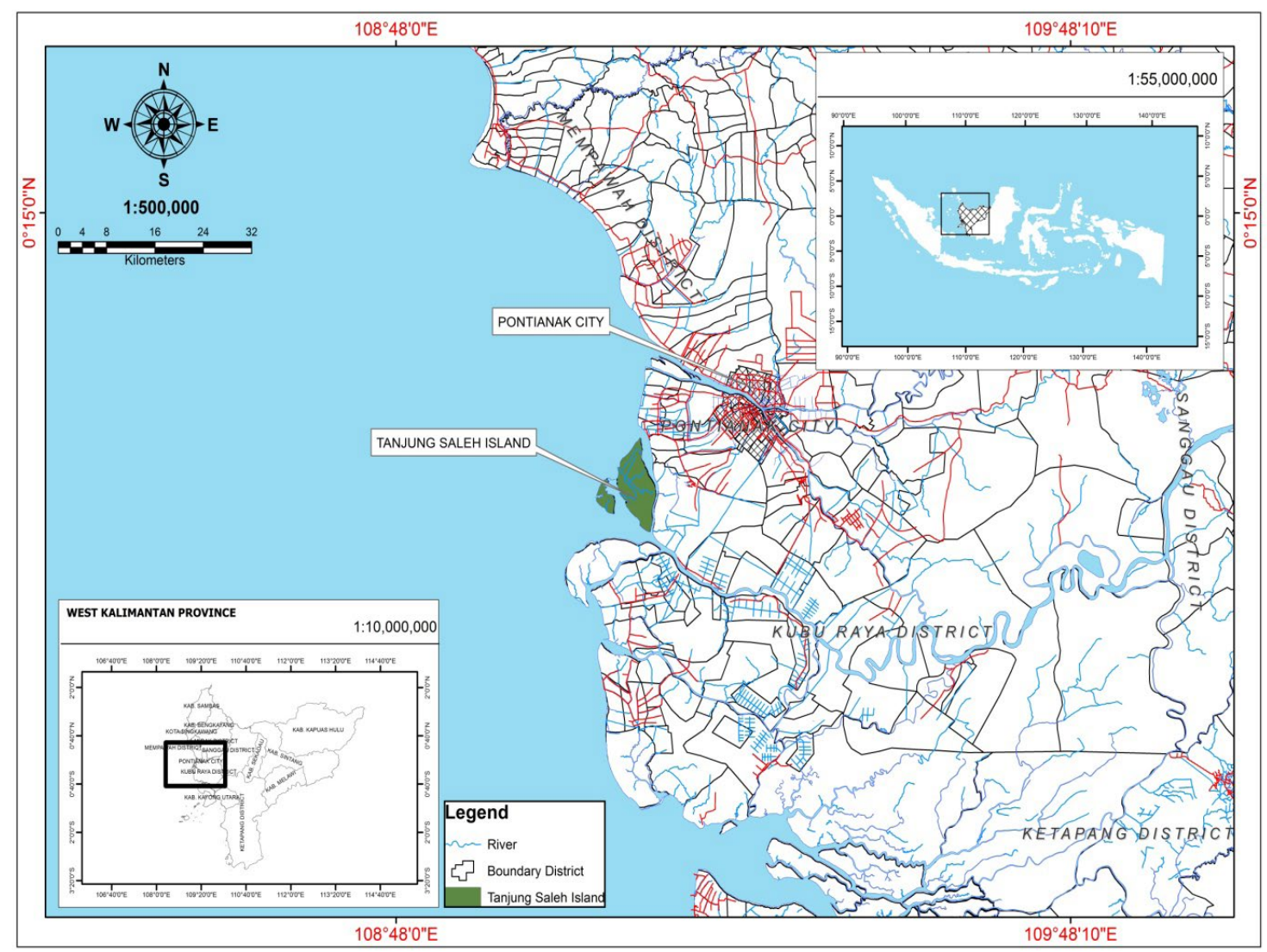

Figure 1. Map of Tanjung Saleh Islands in West Kalimantan Province 
that the area is categorized as poor community in West Kalimantan. Generally, this study is intended to understand the poverty problems in a coastal community. Therefore, this study has been implemented by a case study using qualitative methods refer to Idrus (2009). Data were collected by depth interviews, group interviews, observation, and literature study.

Depth interviews were conducted individually using snowball technique, while group interviews were used to analyze the problems, potency of resources, and poor household needs. Observation method was purposed to get information about direct social phenomena or other activities of fishermen household in study area. Daily pattern of fishermen household was an example of data which collected by direct observation.

Key informants were selected purposely including local economic actors, local government officers, and community leaders who understand well the social and economic condition of the village as site of study. Secondary data were obtained mainly from the village level government and statistic bureau.

Depth interviews were used to interview the poor households, local economic actors, community leaders, and local government officers in the village level. Depth interviews to poor households were intended to know the holistic information about livelihood strategies in fulfillment of household needs and the effort to overcome poverty trap. The interviews to local economic actors were intended to get information about institutional system of local economic activities. Interviews to community leaders were aimed to know about values and norms that influence the livelihood strategies of poor households. Meanwhile, the interviews to local government officers were purposed to get information about program or project concerning economic development or poverty reduction program before. In order to guarantee the successful of interviews, this study needs the choosing of appropriate time so the fishermen can express all important information. Therefore, the interviews were done by visiting to the fishermen's house around 2 to 2.5 hours, usually in the afternoon on 15.00 p.m. to 17.30 p.m. or in the morning after the fishermen done fishing activities.

\section{RESULTS AND DISCUSSION}

Tanjung Saleh village has about $48.28 \mathrm{~km}^{2}$ in wide. It has 5,574 populations and its density is 116 people per $\mathrm{km}^{2}$ (Statistic Bureau of Kubu Raya District, 2014). Refer to this demography composition indicated that the islands has enough populated and it is also indicated the poverty problem. The ethnic in Tanjung Saleh village consist of some tribes such as Malay, Madura, and Bugis. Malay and Madura are majority tribes, while Bugis is minority tribe. Most of households relied on fishing as main livelihood, while the agriculture cultivation still constitute secondary livelihood that is only purposed to guarantee the households food security.

The cause of poverty at Tanjung Saleh islands is characterized by low income that is uncertainty in every time. Low income can cause the limited access to capital accumulation, while low access to technology can cause the limited access to generate household income. Besides, low income can cause lack access to formal education, so they could not compete in getting job opportunity. Moreover, in this village, there is no access to formal financial institution. Meanwhile, the financial institution in central of sub district did not trust to fishermen because difficulties to do suvervision of credit mechanism. This phenomenon is very suitable to poverty circle theory as stated by Soubbotina and Sheram (2000).

The other cause of poverty is limitedness of transportation and agriculture infrastructure. Limitedness of transportation can cause alienation of fishermen household either in economic or social activities. Social alienation in fishermen community, according to Pollnac (1988) can cause negative perspective to formal education, so there are many uneducated children in this island. Meanwhile, limitedness of agriculture infrastructure caused low productivity in agriculture production, whereas this island 
has enoumous agriculture potency.

Natural resources potency of this village can be explored in soil type and climate condition. This area is categorized as tidal lowland and the soil type is "entisols", one of wetland types that enough fertile. According to data of Statistic Bureau of Kubu Raya District (2014) averagely the rainfall is $231 \mathrm{~mm} / \mathrm{month}$ and average of rain days is 14 days/month. The high rate of rainfall in this area actually is potential for developing some agriculture commodities, such as rice farming. But, until now the productivity of rice farm is still low averagely less than 2 ton per hectare, whereas its potency can reach until 6 ton per hectare (Sudrajat 2013). It is caused by still weak of agriculture technology adoption.

\section{Some Types of Livelihood Strategy}

The livelihood strategy that has been done by fishermen household at Tanjung Saleh village can be identified into five types: (a) the strategy that relied on natural resources extraction, (b) traditional agriculture cultivation strategy, (c) household worker utilization strategy, (d) migration strategy, and (e) institutional strategy. Classification of those strategies is based on the effort of households in fulfillment the basic need through utilizing all resources around them.

\section{The Strategy That Relied On Natural Resources Extraction}

This strategy can be identified by fishing activities and harvesting of coastal crops. The fishermen generally still used traditional fishing tools such as gill net and fishing line. Some fishermen also used specific tool to catch specific fish, such as specific tool for fishing of shrimp or crab (Figure 2). Transportation mode of fishing also still used small scale boat that can carry maximum for three people. The zone of fishing not far from the shore, so this fishing zone is still categorized as shallow water zone.

Timing of fishing is done on day or night. If the fishermen want to do the fishing on day, so they go fishing in the morning and will be back in the afternoon around 16.00 p.m., while if they want to do the fishing in the night, so they go fishing in the afternoon and will be back in the night around 12.00 p.m. or 2.00 a.m. The yield of fishing will be sold to the village traders. The local fishermen called the village traders as "bagan". At least there are 10 village traders at Tanjung Saleh village. The yield of fishing not only be sold, but also is consumed by fishermen household it self. Meanwhile, the yield of fishing that could not be sold it will be processed as salted fish.
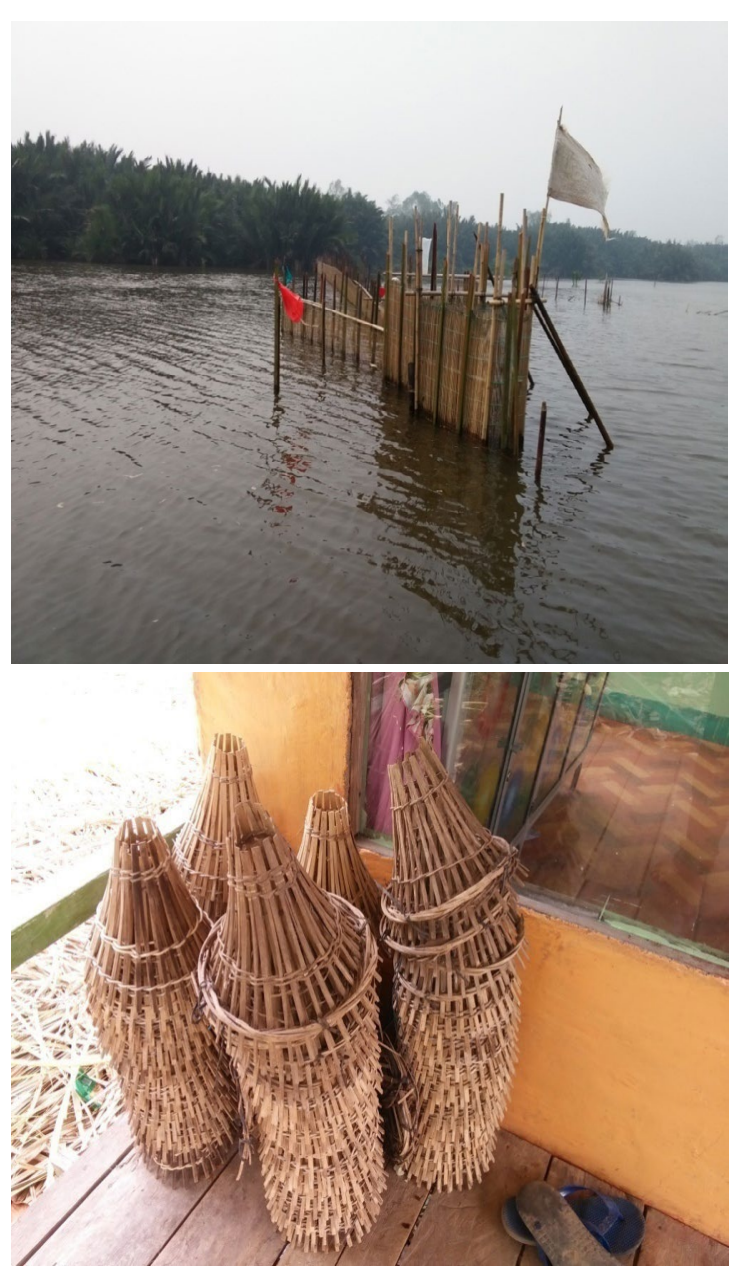

Source: Taken on October $17^{\text {th }}, 2015$

\section{Figure 2. Specific Fishing Tool}

On the other hand, one of the coastal crops that have been utilized is "Nipah" (Nypa fruticans Wurmb) crop. This crop leaves are harvested in a periodic of time. After it is processed by simple way, this product 
will be sold to local market in West Kalimantan Province. This product is used as wrapper of chopped tobacco to make traditional cigarette (Figure 3 ).
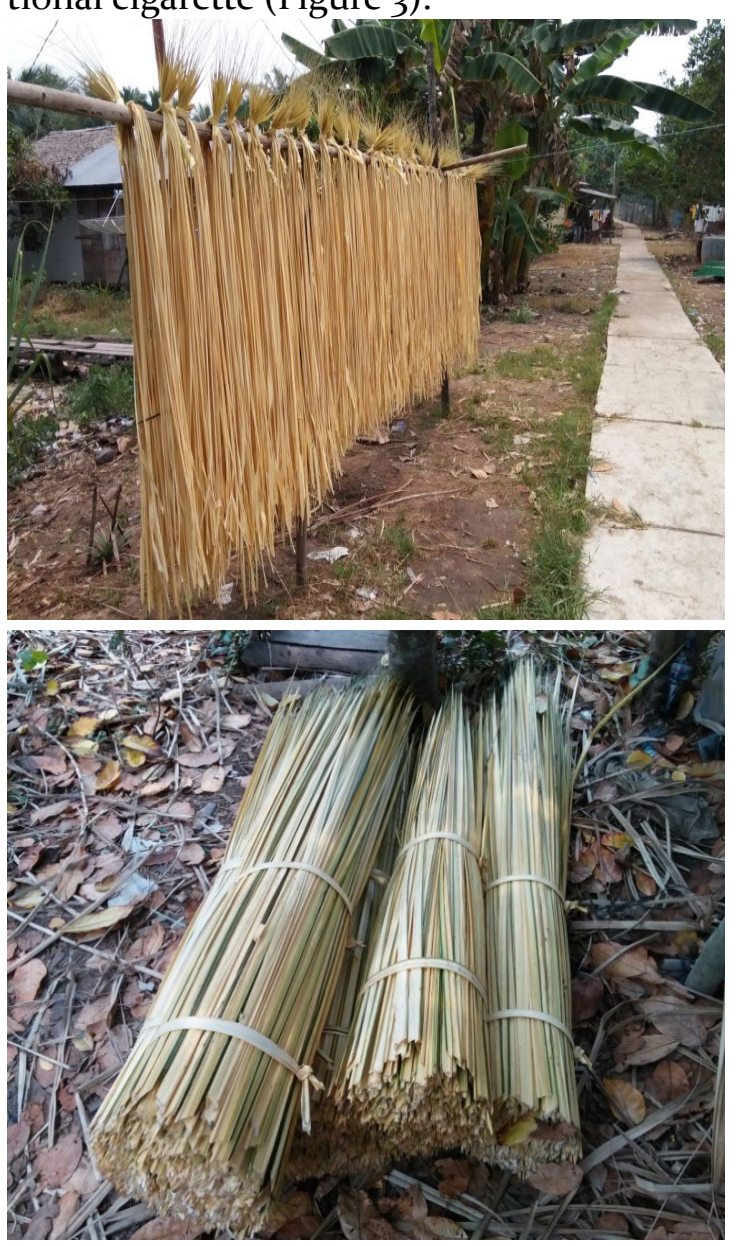

Source: Taken on October $17^{\text {th }}$, 2015

Figure 3. Harvesting of "Nipah" Leaves

\section{Traditional Agriculture Cultivation Strategy}

This strategy comprises rice farming on wetland type (tidal lowland), coconut farming, and livestock farming (duck or cattle). Generally, rice cultivation on wetland type in West Kalimantan is still not intensive yet. The aim of this farming is directed to fulfill the staple food solely (subsistence orientation). Unintensive rice farming is characterized by using of local seed, no preparation or processing of land (slash and burn method solely), and also not intensive in fertilizer technology application. Therefore, the rice farming is only absorp a small number of employees in the community. The rice farming activities are often done by female (fishermen's wife or girl), because the fishermen (male) are more active in fishing activities. This condition is also similar to coconut farming. The worker needs increase in harvest time only. But recently, because the market demand of coconut oil has been substituted by palm oil, the price of coconut is very cheap, so there are many coconut estates which are not maintained by the farmer.

On the other hand, the duck farming has given enough benefit from egg production, but it is still small scale farming, most of them less than 10 ducks per household, only some fishermen household have scale more than 10 ducks. Besides, the cattle farming actually can give benefit to fishermen household, but this farming is only done by Madurese people, because the other tribes are not familiar yet in cattle cultivating.

Based on the existing potency in this village, it is important to improve the productivity some agriculture commodities such as rice and duck farming. Facilitation of rice farming is urgent regarding to adoption of agriculture technology and infrastructure. On the other hand, the improving productivity of duck farming is also rational because duck is aquatic animal that suitable at tidal lowland condition. This idea is also based on the successful of small scale duck farming in this area. Besides, at Tanjung Saleh, there are some byproducts from production process of salted fish that can be used as protein source of duck feed. In order to improve productivity of both commodities, the role of women is an important factor because the fishermen has involved actively in fishing activities.

\section{Household Worker Utilization Strategy}

The fisherman households in Tanjung Saleh also often do some economic strategies to fulfill their basic need. One of the methods is utilizing the household worker to create new income opportunity. It means, the member of household is facilitated actively in generating income. The son is often facilitated in fishing activities meanwhile the girl is facilitated in fish processing such as in production of salted fish (Figure 4). The- 
refore, it is not strange if every fisherman's house has fish dryer place.
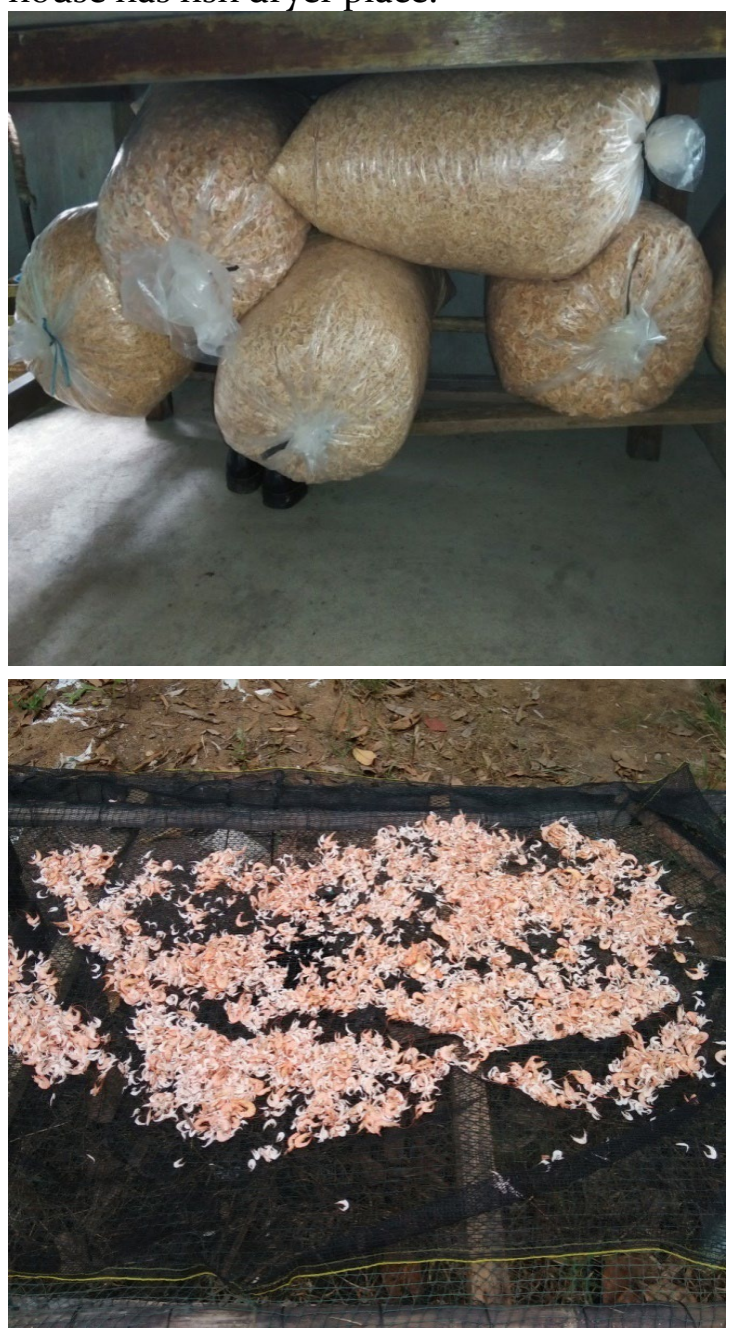

Source: Taken on October $17^{\text {th }}, 2015$

Figure 4. Dried Salted Shrimp Production

\section{Migration Strategy}

The other strategy is migration to urban area such as to Pontianak City or other cities in West Kalimantan. Generally, the migration strategy is done by son or girl. Usually they work in informal sectors, such as household servant, shop servant, etc. This migration is done temporarily as the short run household strategy to cope income problem. It means that the migration strategy is only done if the household has been in depth poverty condition. Usually, migration is done individually based on the accepted information of job opportunity or suggestion from their friends who has been success in migra- tion before.

\section{Institutional Strategy}

One of the institutional strategies in this village is "arisan" (rotational saving and credit association) custom. There are positive aspects of "arisan" custom. It can be a source of capital formation in fishermen household, because it can also be regarded as saving activities. The fishermen custom at Tanjung Saleh is very different with majority fishermen at the other places who have extravagant custom when they get income, as revealed by Nadjib (2001).

Generally, the "arisan"custom can not be separated from women (fishermen's wife) participation in fishermen community. Usually, there are some types of "arisan" custom, depending on agreement among them. Based on its periods of time, some types of "arisan" are weekly or monthly. Membership is based on voluntary principle. The amounts of money in every period of "arisan" are also variety from IDR 10,0oo per week until IDR 10o,ooo per month. Besides, there is type of "arisan" that payment is not fixed. For examples, when Mrs. A in a period of time is getting "arisan", and Mrs. B pay as IDR 100,000, Mrs. C pay as IDR150,00o, and Mrs. D pay as IDR 200,00o, so in next period of time when Mrs. D is getting "arisan" Mrs. A must pay as IDR 200,00o too. In economic perspective, the custom of "arisan" is useful to increase the economic household capability. This custom is also positive to decrease extravagant custom, increasing social cohesion, and developing mutual trust among members of community.

Participation in some types of "arisan" also indicated good condition of an economic household. The operational of "arisan" activities and amount of accumulated money related to yield of fishing directly. So, this phenomenon close related to coastal resources potency as medium of fish growth. This fact clarified the statement that protection of sea resources as a crucial factor in implementing the sustainable livelihood of fishermen community.

Other institutional strategy at Tanjung 
Saleh is partnership between fishermen and village traders in fish marketing. This partnership pattern is very useful for fishermen to guarantee the fish selling. Besides, in one condition a village trader often gives loan to fishermen, through this function, a village trader can be regarded as financial institution. In some moment, a village trader often gives loan to buy boat and fishing tools. The payment of this loan will be done by fishermen when they sell the yield of fishing. This loan is no interest rate and duration of payment is flexible. Actually, the partnership between fishermen and village traders at Tanjung Saleh is very different if it is compared to other places who often exploit the fishermen. There are some reasons for this fact, that the relationship is often based on kinship or brotherhood among them which is done in long term period as stated by Mr. Hermansyah below.

....... the village trader as partner in fish selling is my family, therefore we always trust each other especially in fish price setting ........ (Interview, October $15^{\text {th }}, 2015$ )

Based on description above, it can be expressed some types of livelihood strategy in Tanjung Saleh islands as shown on Table 1.

\section{Exit Strategy from Poverty Trap: The Utilization of Social Capital}

The limitedness access to formal financial institution is responded by fishermen through creating local institution. There are two institutions, patron client relationship (between fishermen and village trader) and "arisan" custom. Both institutions are convinced as important factor in this village.

The patron client relationship is often controversy because this relationship contained negative and positive aspect. Negative aspect of this relationship is often indicated by context that patron get more benefit than client, as shown by the study of Febrianto and Rahardjo (2005). This relationship is often exploitative and created by patron intentionally. But, this relationship also contained positive aspect because it has capable to enhance vertical mobility of the client (Satria 2002). According to Rustinsyah (2011), this relationship usually is characterized by cooperation in long period that indicated there is benefit sharing among actors. This relationship is regarded as indigenous livelihood strategy in South East Asia (Scott 1976) and also as social safety net in rural area (Dharmawan 2007). In Tanjung Saleh, it is proved through close relationship to village traders, the traditional fishermen

Table 1. Type of Fishermen Household Livelihood Strategy in Tanjung Saleh

\begin{tabular}{|c|c|c|}
\hline Type of Livelihood Strategy & Activities & Actors \\
\hline Natural resources extraction & $\begin{array}{l}\text { Fishing activities and harvesting of } \\
\text { "Nipah" leaves }\end{array}$ & Male \\
\hline \multirow[t]{3}{*}{$\begin{array}{l}\text { Traditional agriculture cul- } \\
\text { tivation }\end{array}$} & $\begin{array}{l}\text { Rice farming by slash and burn meth- } \\
\text { od }\end{array}$ & Female and male \\
\hline & Coconut farming & Male \\
\hline & Small scale duck or cattle farming & Male and female \\
\hline $\begin{array}{l}\text { Household worker utiliza- } \\
\text { tion }\end{array}$ & $\begin{array}{l}\text { Participation in fishing activities and } \\
\text { processing of salted fish }\end{array}$ & Male and female \\
\hline Migration & $\begin{array}{l}\text { As worker in informal sector such as } \\
\text { household servant, shop servant, etc. }\end{array}$ & Female and Male \\
\hline \multirow[t]{2}{*}{ Institutional } & $\begin{array}{l}\text { Creating patron client relationships } \\
\text { with village traders to access financial } \\
\text { capital and guarantee in fish marketing }\end{array}$ & Male \\
\hline & $\begin{array}{l}\text { Creating relationships with neighbour } \\
\text { to operate "arisan" custom }\end{array}$ & Female \\
\hline
\end{tabular}

Source: Field Observation (2015) 


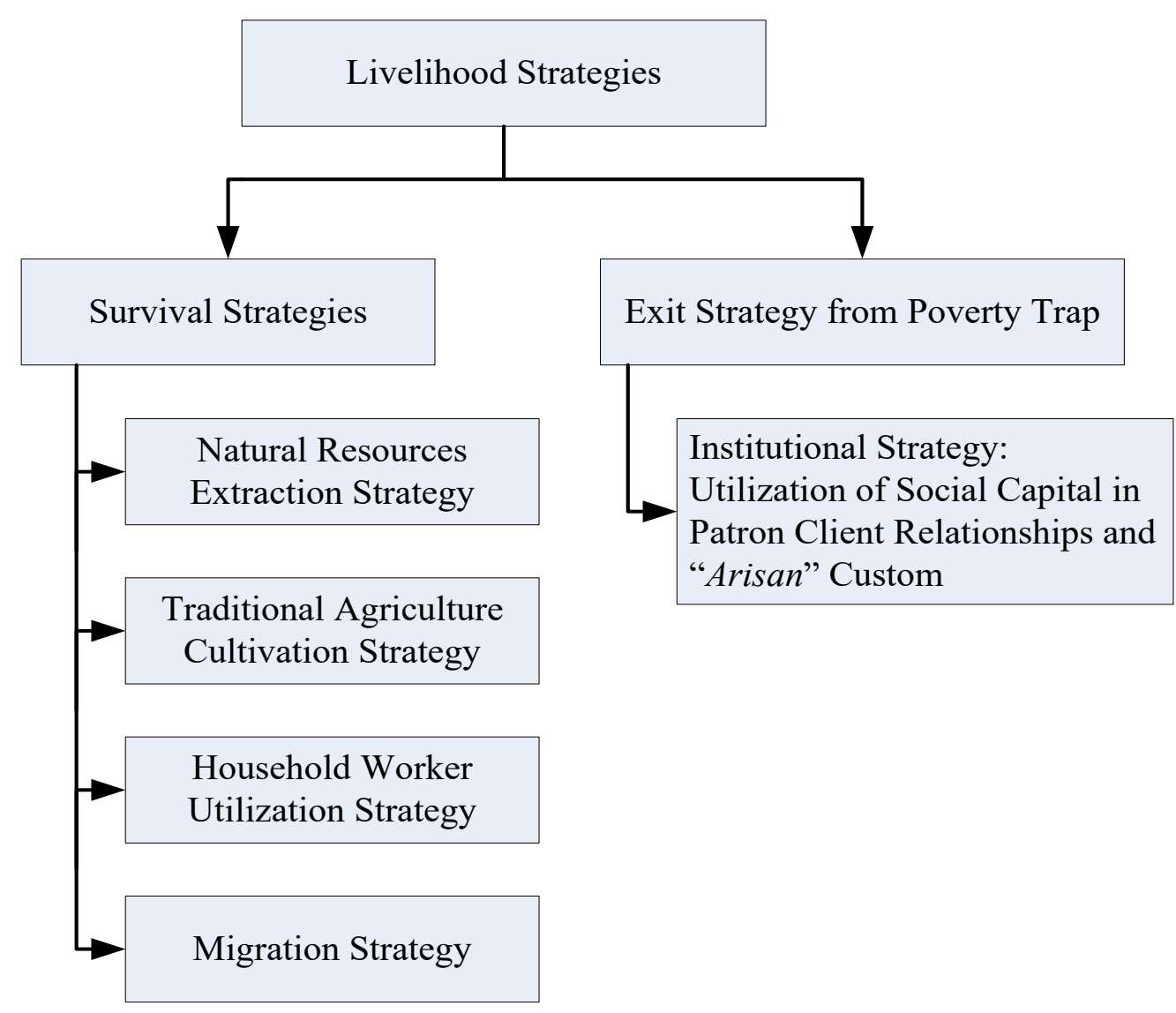

Figure 5. Livelihood Strategies in Tanjung Saleh Islands

can get boat and fishing tool that is very useful in improving the yield of fishing. Thus, its positive aspect is capable to push the fishermen exit from poverty trap.

The existence of positive aspect in patron client relationship close related to weak and strong the social capital on those relationships. A relationship that is relied on strong social capital will enhance the client welfare. The existence of strong social capital (between fishermen and village trader) in Tanjung Saleh is characterized by no interest rate of loan and flexibility on payment duration. It is indicated that there are mutual trust, mutual solidarity, and reciprocity among actors as element of social capital. The existence of social capital can also be found in "arisan" custom that is relied on mutual trust among community members. It means, "arisan" custom is effective facility to nurture the social capital in fishermen community, as the same case has been reported by Anwar et al. (2014) in Barrang
Lompo Island, Makassar-Indonesia. This reality also indicated that social capital is effective in facilitating to access the financial capital. The existence of social capital on both instution is convinced as exit strategy from poverty trap. Thus, the livelihood strategy at Tanjung Saleh can be divided into two types, survival strategy and exit strategy from poverty trap, as ilustrasted in figure 5 .

Social capital is important concept that is accepted widely by social scientist or economist. Nevertheless, social capital can depreciate if it is not nurtured continuously (Wilson 2000; Hasbullah 2006). Therefore, it can be stated that nurturing of social capital in both institutions is important factor to increase the fishermen household welfare or exit from poverty trap. This fact indicated that social capital has provided important proof in coping vulnerability context of poor people.

The importance of social capital on poverty reduction program has been convin- 
ced by many parties in the world including the World Bank. Social capital is proved as main determinant factor for household welfare (Yusuf, 2008). Besides, Rupasingha and Goetz (2007) also show that social capital as main factor in poverty reduction program, and strategy such as improvement of education and providing new employment opportunity, it is uneffective to solve the poverty problem if those strategies are not integrated with social capital implementation. Other finding is showed by Narayan and Pritchett (1999) that social capital is not only strong to increase the household welfare, but also strong to increase household capability.

The important role of social capital to access financial capital at Tanjung Saleh could not be ignored from women (fishermen's wife) participation in the community. Therefore, the women participation is also convinced as important factor in implementing sustainable livelihood strategies. Based on this fact, it is very important to facilitate the women activities at mosque or other activities in the community. For example, the "arisan" custom as women's activities actually can be directed in formating the microfinance institution.

\section{CONCLUSION}

The natural resources at Tanjung Saleh have given supporting to fishermen household livelihood system. It is supported by the soil type and sea water condition that enough fertile. Therefore, it is important to maintain the quality of coastal ecosystem.

The results of this study show that the livelihood strategy at Tanjung Saleh village can be identified into five types: (a) the strategy that relied on natural resources extraction, (b) traditional agriculture cultivation strategy, (c) household worker utilization strategy, (d) migration strategy, and (e) institutional strategy. The institutional strategy is categorized as exit strategy from poverty trap, while the other strategies are categorized as survival strategy. Fact in the field shows that institutional strategy and the role of women are important factor to support the fishermen household livelihood system. There are two institutions often utilized in fishermen community, "arisan" custom and patron client relationship between fishermen and village traders. Through the utilizing of social capital on both institutions, the fishermen household can access the financial capital effectively. Therefore, the nurturing of social capital must be considered in arrangement of sustainable livelihood strategies in fishermen community.

Based on the existing potency in this village, there are two commodities that can be improved in its productivity, rice and duck farming. Both of commodities need facilitation from the government or other institutions. This idea is based on the reason that the poverty problem in this village is more related to low productivity and lack of employment opportunity. The result of this study also shows that the facilitation in farming must be directed to the role of women as an important factor in fishermen community.

\section{ACKNOWLEDGEMENT}

The author gratefully acknowledges to the Research Institution of Tanjungpura University for supporting this study. The author also thank to the village government officers for facilitating the study and all the fishermen households who has participated.

\section{REFERENCES}

Anwar, S.J., L.M. Kolopaking, R.A. Kinseng, and A.V.S. Hubeis. 2014. The impact of State Intervention on Social Capital of Fishermen Community in Small Islands. Jurnal Komunitas. 6(2), pp.246 $-259$.

Balisacan, A. M., Pernia, E. M., and Asra, A., 2003. Revisiting growth and poverty reduction in Indonesia: what do subnational data show?. Bulletin of Indonesian Economic Studies, 39(3), pp.329-351.

Cassels, S., Curran, S. R., and Kramer, R., 2005. Do migrants degrade coastal environments? Migration, natural resource extraction and poverty in North Sulawesi, Indonesia. Human Ecology, 33(3), pp.329-363.

Dharmawan, A.H., 2007. Sistem Penghidupan dan Nafkah Pedesaan: Pandangan Sosiologi Nafkah Mazhab Barat dan Mazhab Bogor. Sodality: Jurnal Transdisiplin Sosiologi, Komunikasi, dan Ekologi Manusia. 1(2), pp. 169-192.

Ellis, F. 1998. Household Strategies and Rural Livelihood Diversification. Journal of Development 
Studies 35(1), pp.1-38.

Fauzi Rachman, N., Savitri, L. A., and Shohibuddin, M. 2009. Questioning pathways out of poverty: Indonesia as an illustrative case for the World Bank's transforming countries. The Journal of Peasant Studies, 36(3), pp.621-627.

Febrianto, P.T. and Rahardjo. 2005. Eksploitasi Hubungan Pandega-Juragan dalam Moderenisasi Perikanan Tangkap di Desa Grajagan, Kecamatan Purwohardjo, Kabupaten Banyuwangi. Sosiosains. 18(2), pp.325-339.

Hasbullah, J., 2006. Social Capital: Menuju Keunggulan Budaya Manusia Indonesia. MR-United Press, Jakarta.

Idrus, M., 2009. Metode Penelitian Ilmu Sosial Pendekatan Kualitatif dan Kuantitatif. Edisi Kedua. Erlangga, Jakarta.

Nadjib, M., 2001. Aspek Sosial Budaya dalam Pengembangan Ekonomi Masyarakat Wilayah Pesisir. Pp. 115-136 in Pengembangan Potensi Sosial Ekonomi Masyarakat Wilayah Pesisir Berkelanjutan, edited by Z. Ismail. Lembaga Ilmu Pengetahuan Indonesia, Jakarta.

Narayan, D. and L. Pritchett., 1999. Cent and Sociability: Household Income and Social Capital in Rural Tanzania. Economic Development and Cultural Change. 47(4), pp.871 - 897.

Pollnac, R.B., 1988. Karakteristik Sosial Budaya dalam Pengembangan Perikanan Berskala Kecil. Pp. 239-283 in Mengutamakan Manusia di dalam Pembangunan: Variabel-variabel Sosiologi dalam Pembangunan Pedesaan, edited by Michael M. Cernea. UI Press, Jakarta.

Reardon, T., J. Berdegue, and G. Escobar., 2001. Rural Non Farm Employment and Income in Latin America: Overview and Policy Implications. World Development. 29(3), pp.395-409.

Rupasingha, A. and S.J. Goetz., 2007. Social and Political Forces as Determinant of Poverty: A Spatial Analysis. The Journal Socio-Economic. 36, pp.650-671.
Rustinsyah. 2011. Hubungan Patron-Klien di Kalangan Petani Desa Kebonrejo. Jurnal Masyarakat Kebudayaan dan Politik. 24(2), pp.176-182.

Satria, A., 2002. Pengantar Sosiologi Masyarakat Pesisir. Jakarta: Cidesindo.

Scott, J.C., 1976. The Moral Economy of The Peasant: Rebellion and Subsistence in Southeast Asia. New Haven: Yale University Press.

Soubbotina, T.P. and K.A. Sheram., 20oo. Beyond Economic Growth Meeting the Challenges of Global Development. The World Bank, Washington D.C.

Statistic Bureau of Kubu Raya District. 2014. Sungai Kakap Sub District in Figure 2014. Statistic Bureau of Kubu Raya District, Kubu Raya.

Sudrajat, J., 2013. Potensi dan Problematika Pengembangan Wilayah Pesisir di Kalimantan Barat. Journal Social Economic of Agriculture. 2(1), pp.29-41.

Suryahadi, A., Priyambada, A., and Sumarto, S., 2005. Poverty, school and work: Children during the economic crisis in Indonesia. Development and Change, 36(2), pp.351-373.

Suryahadi, A., Suryadarma, D., and Sumarto, S., 2009. The effects of location and sectoral components of economic growth on poverty: Evidence from Indonesia. Journal of Development Economics, 89(1), pp.109-117.

Warr, P., 2005. Food policy and poverty in Indonesia: a general equilibrium analysis. Australian Journal of Agricultural and Resource Economics, 49(4), pp.429-451.

Wilson, P.N., 20oo. Social Capital, Trust, and the Agribusiness of Economics. Journal of Agricultural and Resource Economics. 25(1), pp.1-13.

Yusuf, S.A., 2008. Social Capital and Household Welfare in Kwara State, Nigeria. Journal of Human Ecology. 23(3), pp.219-229. 